\title{
Communication
}

\section{Design, Modeling and Synthesis of 1,2,3-Triazole-Linked Nucleoside-Amino Acid Conjugates as Potential Antibacterial Agents}

\author{
Sarah N. Malkowski (D), Carolyn F. Dishuck (D), Gene G. Lamanilao (D), Carter P. Embry, \\ Christopher S. Grubb, Mauricio Cafiero and Larryn W. Peterson * \\ Department of Chemistry, Rhodes College, 2000 North Parkway, Memphis, TN 38112, USA; \\ snmalkowski@gmail.com (S.N.M.); cdishuck@gmail.com (C.F.D.); gene.lamanilao@gmail.com (G.G.L.); \\ embcp-19@rhodes.edu (C.P.E.); csg2140@cumc.columbia.edu (C.S.G.); cafierom@rhodes.edu (M.C.) \\ * Correspondence: petersonl@rhodes.edu; Tel.: +1-901-843-3545
}

Received: 16 September 2017; Accepted: 3 October 2017; Published: 10 October 2017

\begin{abstract}
Copper-catalyzed azide-alkyne cycloadditions (CuAAC or click chemistry) are convenient methods to easily couple various pharmacophores or bioactive molecules. A new series of 1,2,3triazole-linked nucleoside-amino acid conjugates have been designed and synthesized in $57-76 \%$ yields using $\mathrm{CuAAC}$. The azido group was introduced on the $5^{\prime}$-position of uridine or the acyclic analogue using the tosyl-azide exchange method and alkylated serine or proparylglycine was the alkyne. Modeling studies of the conjugates in the active site of LpxC indicate they have promise as antibacterial agents.
\end{abstract}

Keywords: click chemistry; CuAAC; 1,2,3-triazole; nucleoside; LpxC; antibacterial

\section{Introduction}

Copper-catalyzed azide-alkyne cycloaddition (CuAAC) reactions, also commonly known as click chemistry, are widely used in a variety of interdisciplinary fields such as organic synthesis, combinational chemistry, drug development, materials science, and bioorthogonal chemistry [1]. They require an azide and an alkyne to form a 1,2,3-triazole ring in the presence of $\mathrm{Cu}(\mathrm{I})$ ions. The use of CuAAC in bioorthogonal chemistry offers a multitude of advantages. The necessary alkyne and azide moieties share properties that are ideal under the conditions of bioorthogonal chemistry, such as their small size, stability, and absence within biological systems, preventing the disruption of native chemical reactions and structures within the studied system. The CuAAC reaction has fast kinetics and high yield [1]. The stability of the signature 1,2,3-triazole ring also protects the bioactive conjugates from metabolic degradation and allows for tolerance of a diverse range of reaction conditions, chemical environments, and reagents [1,2].

In addition to facilitating bioorthogonal chemical reactions, a broad assortment of triazole derivatives readily synthesized via CuAAC have shown promising results within the field of medicinal chemistry, with certain triazoles displaying antifungal activity against several Candida species [3]. Additionally, CuAAC has made it possible for researchers to prepare novel phospholipid-protein conjugates with high binding affinity for autoimmune antibodies [4]. Recent studies have described the use of 1,2,3-triazolyl nucleosides and nucleoside analogues as chitin synthase inhibitors [5], phosphoglycosyltransferase inhibitors [6] and anticancer [7-9], antiviral [10,11] and antimicrobial agents [12-14]. These developments, as well as the results described in this paper, highlight the practicality and versatility of the CuAAC reactions.

Although there have been many great technological advances in the health industry, the treatment of microbial diseases, including bacterial, viral, and parasitic infections, remains a challenge [15]. 
Among the culprits of such infections are Gram-negative bacteria, such as E. coli and P. aeruginosa [16-18]. To further complicate problems, multidrug-resistant strains of Gram-negative bacteria present potential serious health issues [18]. The bacterial resistance and difficulty in treating Gram-negative bacterial infections have prompted researchers to develop novel and effective antibacterial therapies [17].

The outer membrane of Gram-negative bacteria is composed of lipopolysaccharide (LPS). An integral component of LPS is lipid A, which is a glucosamine-based phospholipid. Lipid A anchors LPS to the outer membrane and is essential for the growth and viability of the bacterium [17]. There are nine enzymes involved in the biosynthetic pathway of Lipid A [18]. Among these enzymes is UDP-3-O-(R-3-hydroxymyristoyl)- $N$-acetylglucosamine deacetylase (LpxC). LpxC is responsible for catalyzing the first committed step in the synthesis of lipid A [18], and therefore, it is an attractive target for inhibiting the biosynthesis of lipid A, resulting in a compromised outer membrane.

Information from previous inhibitors and the structure of the natural substrate influenced rational design of the conjugates' structures. The natural substrate features three regions: a sugar with a hydrophobic tail (black), a zinc-binding motif (red), and a uracil-based nucleoside (blue) (Figure 1A). The initial design of the conjugates featured a hydroxamic acid to bind to the zinc ion and a uracil-based nucleoside (Figure 1B). The hydrophobic moiety was initially omitted for synthetic ease. The analogues are synthesized in two building blocks, the nucleoside block and the hydrophobic moiety with the hydroxamic acid, and then clicked together to form the triazole linkage (Figure 1B).

A

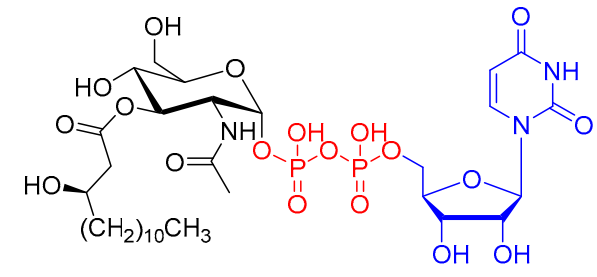

B

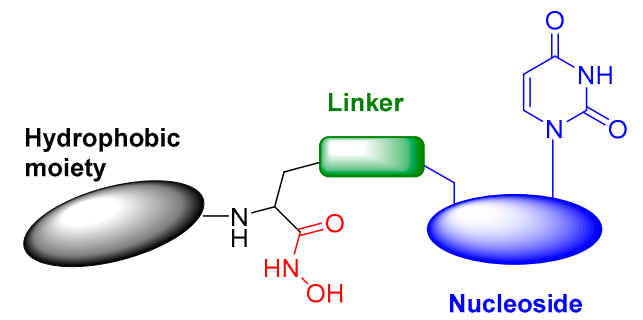

Figure 1. (A) The structure of the natural substrate of LpxC; (B) General structure of the triazolelinked conjugates.

Herein, we report the design, computational analysis and synthesis of four novel nucleosideamino acid conjugates $\mathbf{1 a}, \mathbf{2 a}, \mathbf{3}$ and 4 (Figure 2) conveniently coupled via CuAAC, positioning a 1,2,3-triazole group in the center of the molecule, linking the nucleoside and amino acid. We chose to use amino acids because their properties can be easily modified and the carboxylic acid can be conveniently converted to a hydroxamic acid.
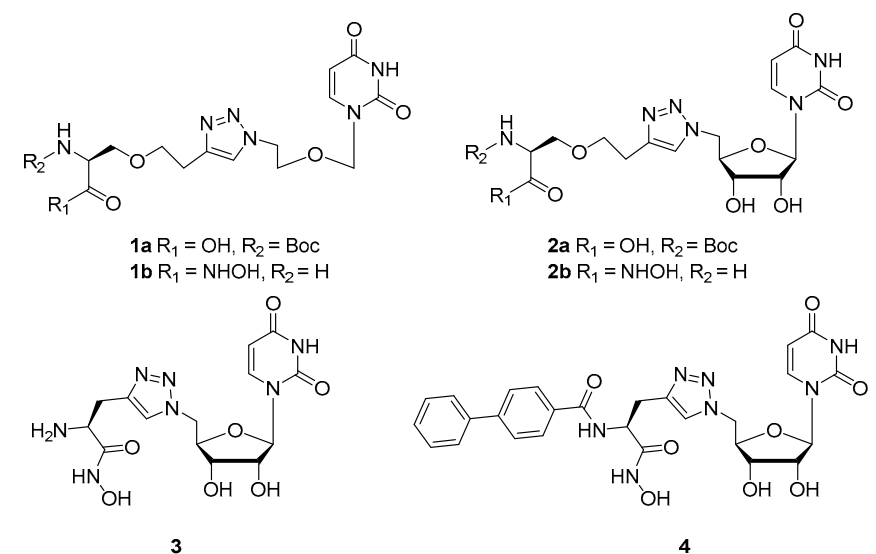

Figure 2. The structures of the nucleoside-amino acid conjugates.

Not only does the use of the click reaction provide the above-mentioned advantages, these compounds or their derivatives could be further functionalized to include additional amino acids or groups off 
the amino group of serine (Ser) or propargylglycine that would further modulate their activity or properties. The modeling studies confirmed that these conjugates bind in the active site of LpxC and provided further insight into which conjugates show the most promise as inhibitors of LpxC.

\section{Results and Discussion}

\subsection{Computational}

The triazole-linked conjugates were optimized in the LpxC active site using the M06-L [19] density functional theory methods with the 6-31G [20] basis set. The ligands were placed in a truncated active site (His265, Gly264, His58, Phe192, Phe194, Glu197, and Lys239) in an initial configuration similar to the natural substrate (from the crystal structure) [21]. The positions of the ligands and amino acid residue side chains were optimized in both a vacuum model and a solvated model. For the solvated model, we used implicit solvation with water via the PCM using default parameters [22]. Counterpoise-corrected [23] electronic interaction energies were calculated for the ligand and $\mathrm{Zn}^{2+}$ and the ligand and all amino acid residues in both conditions using M06-L and the 6-311+ $\mathrm{G}^{*}$ basis set.

The results of the counterpoise-corrected electronic interaction energies of compounds $\mathbf{1 b}, \mathbf{2} \mathbf{b}$ and 3 in the vacuum model are shown in Table 1. Negative numbers indicate attractive forces. Conjugates $\mathbf{1 b}$ and $\mathbf{2 b}$ were evaluated as hydroxamic acids to ensure the strongest interaction with the zinc ion. Nonetheless, in the vacuum model, conjugate 3 shows the most favorable interaction energy in the active site, with a large percentage of the total interaction energy coming from the interaction between the ligand and the zinc ion. Compounds $\mathbf{1 b}$ and $\mathbf{2} \mathbf{b}$ were designed to have added flexibility to adopt the optimal conformation and binding within the LpxC active site. However, there is a possibility the compounds had too much rotational freedom, resulting in lower interaction energies. Due to the less favorable computational results of compounds $\mathbf{1} \mathbf{b}$ and $\mathbf{2} \mathbf{b}$, they were not investigated further.

Table 1. Interaction energies in $\mathrm{kcal} / \mathrm{mol}$.

\begin{tabular}{ccccc}
\hline \multirow{2}{*}{ Compound } & \multicolumn{2}{c}{ Vacuum Model } & \multicolumn{2}{c}{ Solvated Model } \\
\cline { 2 - 5 } & $\mathbf{Z n}^{\mathbf{2 +}}$ & Total & $\mathbf{Z n}^{2+}$ & Total \\
\hline $\mathbf{1 b}$ & -296 & -544 & nd & nd \\
$\mathbf{2 b}$ & -293 & -529 & nd & nd \\
$\mathbf{3}$ & -496 & -613 & -491 & -710 \\
$\mathbf{4}$ & nd & nd & -470 & -602 \\
\hline
\end{tabular}

The results of the counterpoise-corrected interaction energies of the solvated model are summarized in the third and fourth columns of Table 1. The solvated model can be considered a more realistic model, as it is more representative of the conditions in vivo. Due to the favorability of compound 3 in the vacuum model, only 3 and 4 were investigated in the solvated model. It was concluded that 3 exhibits the strongest interaction energy because of the hydroxamic acid oxygen interacting with the backbone $\mathrm{NH}_{2}$ of the histidine residue. These computational studies suggest that 3 and $\mathbf{4}$ may act as inhibitors of LpxC, where a nitrogen in the triazole ring provides an additional point of interaction with zinc.

The optimized complexes are shown in Figure 3. Since the $\mathrm{Zn}^{2+}$ ion in the active site has a positive charge, it can bind with any portion of the substrate that is partially negative. The ligand binds $\mathrm{Zn}^{2+}$ using the oxygens of the hydroxamic acid, producing a very strong attractive interaction. However, our results showed the triazole group also binds well to zinc, which may strengthen binding in the active site. All four conjugates bound $\mathrm{Zn}^{2+}$ through the hydroxamic acid oxygens and with a nitrogen in the triazole ring. Lys239 and His58 have strong attractive interactions with conjugate 4 . This is because the ligand has a -1 charge and both lysine and histidine are positively charged. The glutamate residues in the active site have strong repulsive interactions with $\mathbf{4}$ since glutamate is negatively charged, as is compound 4. 


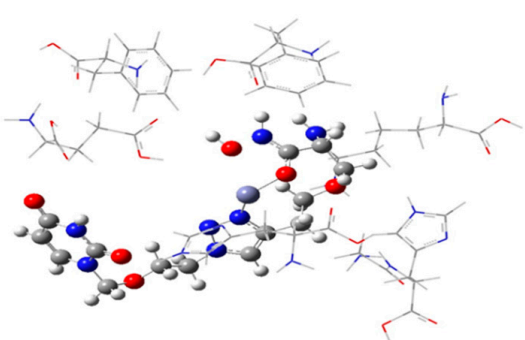

$1 b$

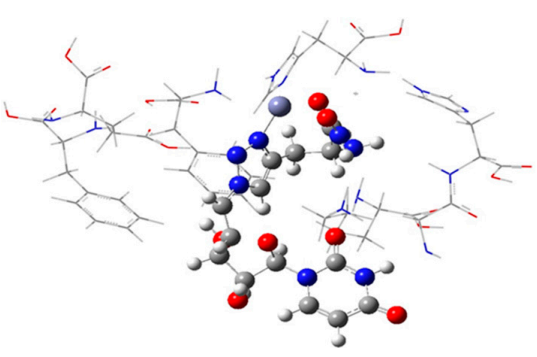

3

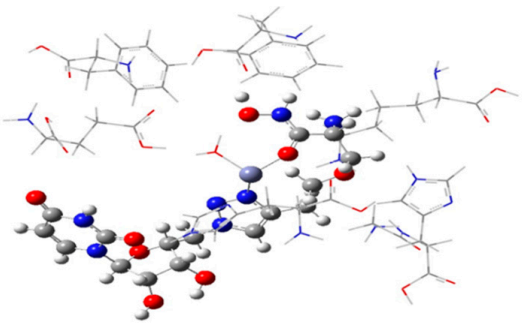

$2 b$

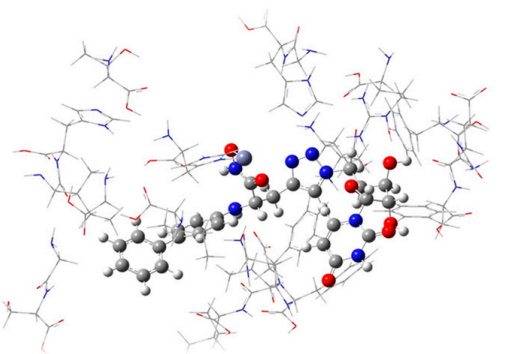

4

Figure 3. Optimized conformations of conjugates $\mathbf{1 b}, \mathbf{2 b}, \mathbf{3}$ and $\mathbf{4}$ in the truncated LpxC active site. The purple atom is $\mathrm{Zn}^{2+}$. Conjugates $\mathbf{1} \mathbf{b}$ and $\mathbf{2} \mathbf{b}$ were optimized in vacuo, while $\mathbf{3}$ and $\mathbf{4}$ were evaluated in the solvated model.

\subsection{Synthesis}

To synthesize the acyclic nucleoside 5, uracil was reacted with 1,3-dioxolane according to the published procedure [24] to produce 5 in a 33\% yield, (Scheme 1). The acyclic nucleoside 5 was tosylated in 6, followed by exchanging the tosylate for an azide 7 (Scheme 1) [25]. In our hands, tosylation of the acyclic nucleoside analogue proved to be difficult. Various attempts to synthesize 6 are depicted in Supplementary Table S1. A review of the literature for more successful methods was unproductive [25-29]. Both tosyl anhydride $\left(\mathrm{Ts}_{2} \mathrm{O}\right)$ or tosyl chloride $(\mathrm{Ts} C \mathrm{l})$ have been used, as well as the presence or absence of an aqueous workup. Pure tosylate 6 was obtained with a yield of $23 \%$ and a clean ${ }^{1} \mathrm{H}-\mathrm{NMR}$. The azide reaction proceeded with success to about $70 \%$ yield. Similar reactions have been perfomed resulting in higher yields [29]. However, differences in solubility and polarity of their 5,6-substituted uracil analogue likely played a role in the inconsistency in their reported yield and what we obtained.

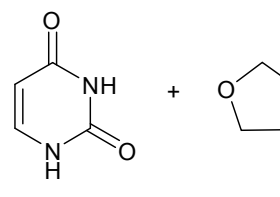

$\mathrm{CH}_{3} \mathrm{CN}$, bis(TMS)acetamide $\mathrm{KI},\left(\mathrm{CH}_{3}\right)_{3} \mathrm{SiCl}, \mathrm{rt}, 16 \mathrm{~h}$ $\mathrm{HO}$<smiles>O=c1ccn(COCCO)c(=O)[nH]1</smiles>
$33 \%$

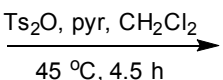

$23 \%$<smiles>O=c1ccn(COCC(F)(F)F)c(=O)[nH]1</smiles><smiles>N#CCOCn1ccc(=O)[nH]c1=O</smiles>

Scheme 1. Synthesis of the azido acyclic nucleoside 7.

Synthesis of the acyclic nucleoside-Ser conjugate is illustrated in Scheme 2. Commercially available Boc-L-Ser was alkylated with bromobutyne to produce 8 (Scheme 2). The alkylation reaction was 
first attempted using $\mathrm{NaH}$ as the base, producing 8 in 10-23\% yields [30]. Due to the poor yields and inconsistent purity of the compound, a different method was sought. Using $\mathrm{K}_{2} \mathrm{CO}_{3}$ as a base, 8 was obtained in a yield of 38\% [31].
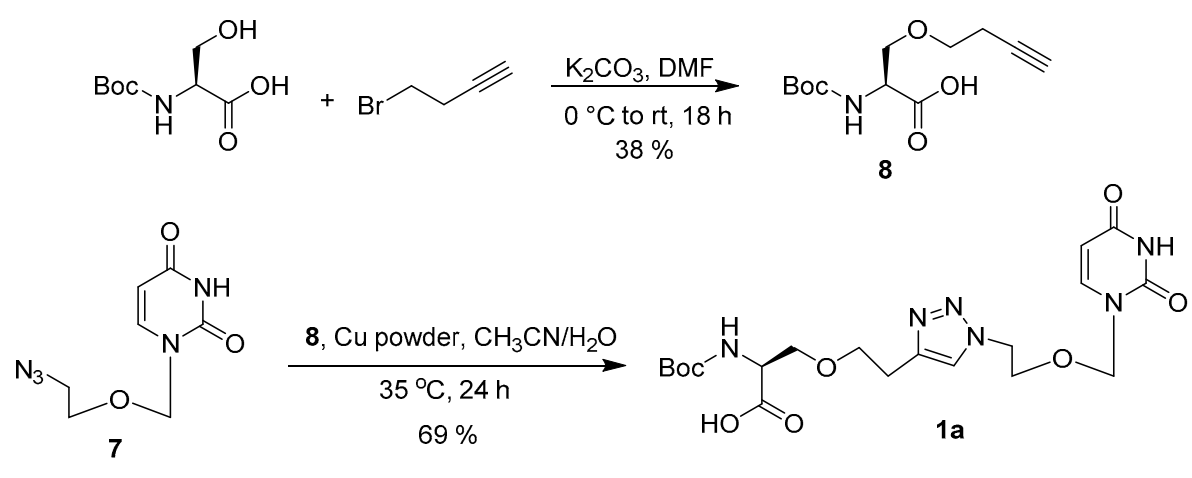

Scheme 2. Synthesis of acyclic nucleoside conjugate 1a.

CuAAC was used to create the 1,2,3-triazole linkage to couple the nucleoside analogue and amino acid. Azide 7 and alkyne 8 were coupled together to form 1a [32]. Despite the difficulty in preparation of the azide and alkyne, the click reaction proceeded with ease, providing 1a in a 69\% yield. Silica gel column chromatography eluted a pure compound, despite the impurities present in the azide.

The remaining conjugates 2-4 were synthesized from the protected $5^{\prime}$-azido uridine 11, which was synthesized in three steps (Scheme 3). Beginning with a ketal protection of the $2^{\prime}$ - and $3^{\prime}$-hydroxyl groups on commercially available uridine to produce 9 (Scheme 3) [33]. The ketal production proceeded with ease, attaining a high yield of $91 \%$. Following the protection, a tosylation reaction was performed to activate the 5'-hydroxyl group, producing 11 (Scheme 3) [25]. Once again, the tosylation reaction proceeded with some difficulty. There are literature procedures describing the use of either $\mathrm{Ts}_{2} \mathrm{O}$ or $\mathrm{TsCl}$, both of which have been used with pyridine, as well as in the presence or absence of dichloromethane $[25,34]$. Various reaction conditions were attempted to determine the optimal conditions to produce a pure product in a high yield, including running the reaction for 2-4 h or overnight, at room temperature or slightly heated. Despite the literature [25] reporting a $98 \%$ yield on the formation of the tosylate, in our hands a maximum of $77 \%$ yield has been obtained with $\mathrm{Ts}_{2} \mathrm{O}$ and dichloromethane under a $2 \mathrm{~h}$ reflux. The tosyl group in $\mathbf{1 1}$ was replaced by an azide group in accordance with the literature procedure [25] (Scheme 3). The yields for this reaction are comparable to the literature.<smiles>O=c1ccn(C2OC(CO)C(O)C(O)C2O)c(=O)[nH]1</smiles><smiles>CC1(C)OC2C(COC(F)(F)F)OC1C2n1ccc(=O)[nH]c1=O</smiles>

10

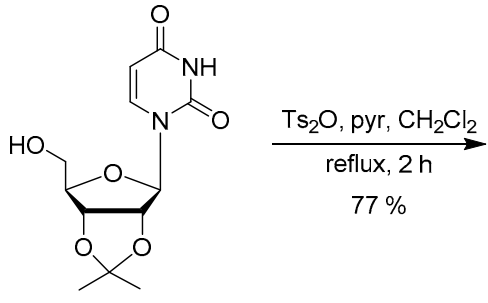

9

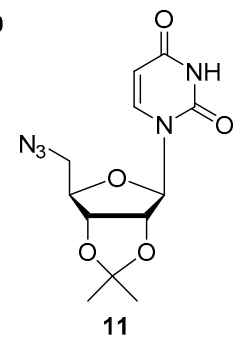

Scheme 3. Synthesis of the azidonucleoside 11. 
Alkyne $\mathbf{8}$ and azide $\mathbf{1 1}$ were clicked together to form the uridine-Ser conjugate $\mathbf{2 a}$ as shown in Scheme 4 . Initially the reaction ran $48 \mathrm{~h}$ with a copper wire-wrapped stir bar to provide product $\mathbf{2 a}$ in $45 \%$ yield [32]. However, when Cu powder was used, the reaction yield improved significantly to $76 \%$. Due to the synthetic challenges observed in the preparation of $\mathbf{1 a}$ and $\mathbf{2 a}$, further deprotection and conversion to the hydroxamic acid was not pursued.

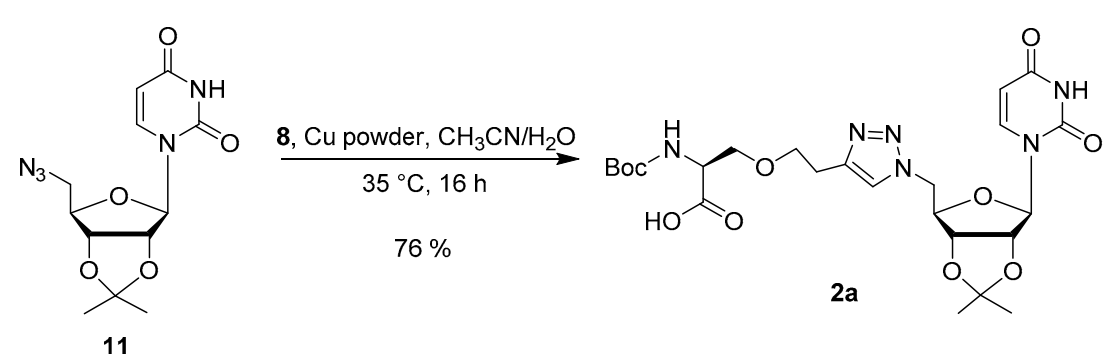

Scheme 4. CuAAC of 8 and 11.

Following the challenges with alkylating Boc-L-Ser, we envisioned the use of propargylglycine to bypass the need for the alkylation reaction. Therefore, commercially available L-propargylglycine was used as the amino acid to click to the nucleoside. The use of propargylglycine provides significant advantages in that it allows further functionalization of the amino acid, including the convenient coupling of another amino acid or any other pharmacophore on either the nitrogen or carboxylic acid and the conversion to a hydroxamic acid or ester.

The synthesis of the uridine-propargylglycine conjugates began with the conversion of the carboxylic acid of L-propargylglycine to the protected hydroxamic acid intermediates $\mathbf{1 2}$ and $\mathbf{1 3}$. Compound 12 was successfully synthesized with an $82 \%$ yield using commercially available Boc-L-propargylglycine and $\mathrm{O}$-(tetrahydro-2H-pyran-2-yl)hydroxylamine (THP-hydroxylamine), 2-chloro-4,6-dimethoxy-1,3,5-triazine (CDMT) and N-methylmorpholine (NMM) (Scheme 5) [35]. Commercially available Fmoc-L-propargylglycine was initially converted to the protected hydroxamic acid 13 using CDMT and NMM [35]. However, when standard dicyclohexylcarbodiimide (DCC) coupling was used, purification was easier and higher yields were obtained. Next, the Fmoc protecting group was removed using a 20\% solution of piperidine in dimethylformamide (DMF), and immediately coupled with biphenyl-4-carboxylic acid using 1-ethyl-3-(3-dimethylaminopropyl)carbodiimide (EDC) to produce $\mathbf{1 4}$ in a 35\% yield over the two steps (Scheme 5) [36]. Not surprisingly, the use of diethylamine and longer reaction times during the Fmoc deprotection resulted in lower yields and racemization.

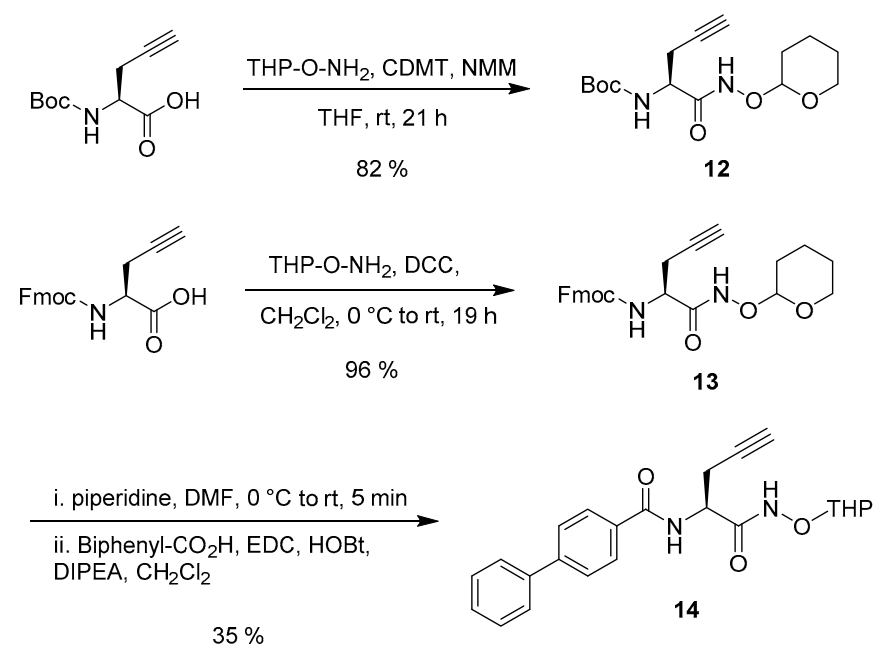

Scheme 5. Preparation of alkynes 12 and 14. 
Following preparation of the appropriate alkynes 12 and 14, they were coupled to azide 11 via a $\mathrm{Cu}$-catalyzed cycloaddition [32] (Scheme 6). The click reaction was first sonicated for 10-15 min before stirring overnight and proceeded in 76 and 57\% yields. Finally, the Boc group was removed (3) and the 2 ' - and 3'-hydroxyl groups were deprotected with trifluoroacetic acid (TFA) to yield 3 and 4 in an $83 \%$ and $70 \%$ yield, respectively (Scheme 6). The final products were precipitated from a methanolic solution using diethyl ether. The final conjugates 3 and 4 were characterized by ${ }^{1} \mathrm{H}$ - and ${ }^{13} \mathrm{C}-\mathrm{NMR}$ and HRMS. The purity was confirmed by HPLC.

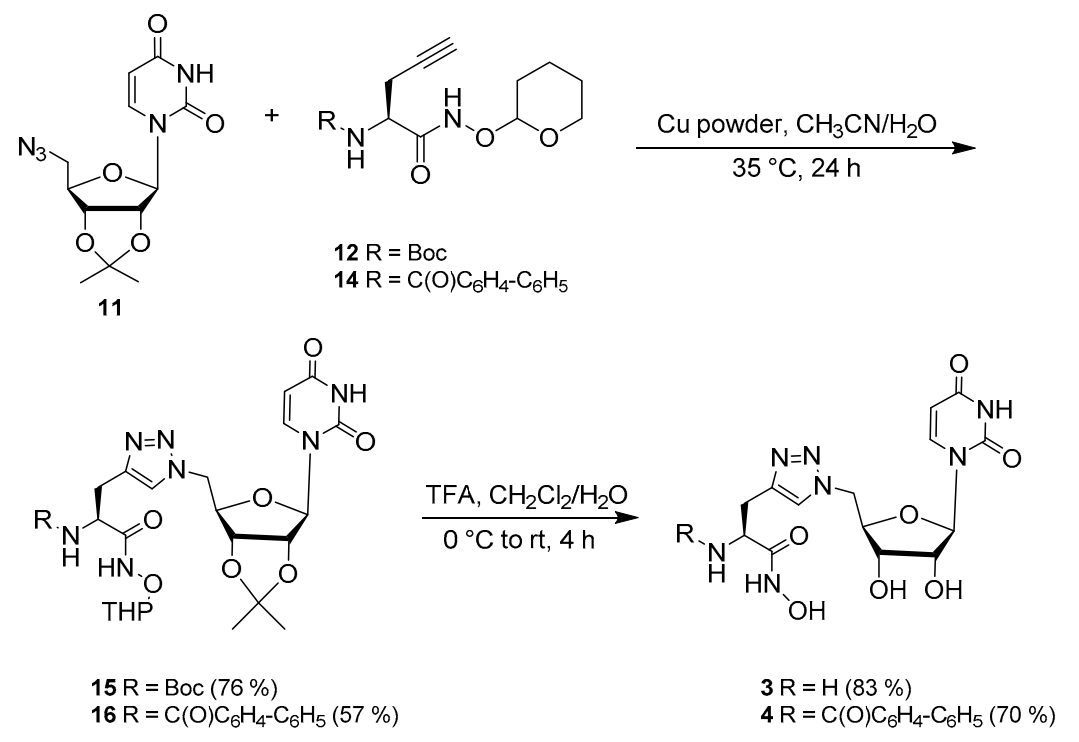

Scheme 6. Synthesis of compounds 3 and 4.

The structure of 4 was also confirmed by ${ }^{1} \mathrm{H}-{ }^{1} \mathrm{H}$ COSY and 2D-NOESY experiments (Supplementary Figures S1 and S2). NOE correlations were observed between H-6 and H-5', $\mathrm{H}-2^{\prime}$ and $\mathrm{H}-5^{\prime}, \mathrm{H}-\mathrm{1}^{\prime}$ and $\mathrm{H}-4^{\prime}$, and $\mathrm{H}-\alpha$ and $\mathrm{H}-2^{\prime \prime}$ and $\mathrm{H}-\mathrm{N}$ and $\mathrm{H}-2^{\prime \prime}$ (Figure 4). Interestingly, there were no correlations observed for the amino acid methylene protons. Although some of the ${ }^{1} \mathrm{H}$ signals are overlapping, the NOESY crosspeaks confirmed the presence of the expected 1,4-disubstituted-1,2,3-triazole.

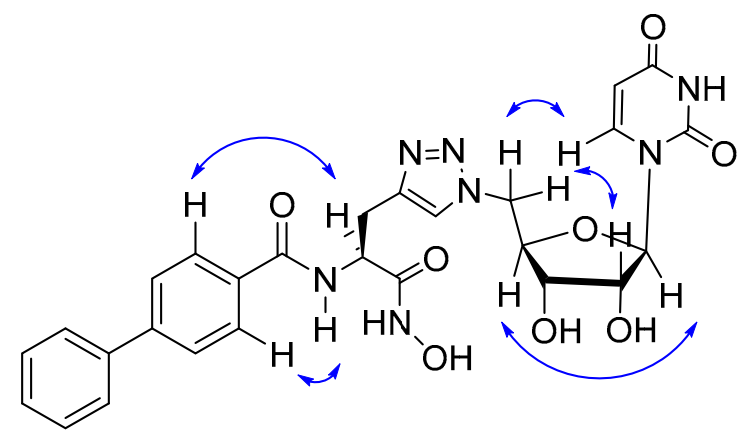

Figure 4. Key NOESY correlations of 4.

\section{Materials and Methods}

\subsection{General Methods}

Unless otherwise indicated, all anhydrous solvents were commercially obtained and stored in Sure-Seal bottles under argon. All other reagents and solvents were purchased as the highest grade available from Acros (Fisher Scientific, Pittsburgh, PA, USA) or Sigma-Aldrich (St. Louis, MO, USA) 
and were used without further purification. Boc-L-Propargylglycine was purchased from Aurum Pharmatech (Franklin Park, NJ, USA) and Fmoc-L-propargylglycine was purchased from AK Scientific (Union City, CA, USA). All moisture-sensitive reactions were carried out using dry solvents and under slight pressure of ultra-pure argon. Commercially available disposable syringes were used for transferring reagents and solvents. All single syntheses were conducted in conventional flasks under an atmosphere of dry argon. Proton $\left({ }^{1} \mathrm{H}\right)$ and carbon $\left({ }^{13} \mathrm{C}\right) \mathrm{NMR}$ spectra were recorded on a $400 \mathrm{MHz}$ spectrometer (Varian, Palo Alto, CA USA). NMR data are reported as follows: chemical shifts $(\delta)$ are reported in parts per million $(\mathrm{ppm})$ referenced to ${ }^{1} \mathrm{H}\left(\mathrm{CDCl}_{3}\right.$ at $7.27, \mathrm{CD}_{3} \mathrm{OD}$ at 3.31 , DMSO- $d_{6}$ at 2.50$),{ }^{13} \mathrm{C}\left(\mathrm{CDCl}_{3}\right.$ at $77.16, \mathrm{CD}_{3} \mathrm{OD}$ at $49.00, \mathrm{DMSO}-d_{6}$ at 39.52), multiplicity (s = singlet, br $\mathrm{s}=$ broad singlet, $\mathrm{d}=$ doublet, $\mathrm{dd}=$ doublet of doublets, $\mathrm{t}=$ triplet, $\mathrm{q}=$ quartet, quin = quintet, $\mathrm{m}=$ multiplet) and coupling constants $(J)$ are reported in Hz. Column chromatography was conducted using silica gel (Silicycle 55-65 A). Purity of the compounds was confirmed to be greater than 95\% via HPLC analysis (LC-6AD pumps, detection with a SPD-M20A PDA and CBM-20A communication, Shimadzu, Columbia, MD, USA) and a Hypersil Gold C18 column, $(250 \times 4.6 \mathrm{~mm}$, particle size $=5 \mu \mathrm{m}$, Thermo Fisher Scientific, Waltham, MA, USA). High resolution mass spectra (HRMS) were obtained in the University of California Riverside High Resolution Mass Spectrometry facility using +ESI.

\subsection{Computational Methods}

Starting from the LpxC crystal structure with the natural substrate bound in the active site (PDB ID:2IER) [21], proposed analogues were placed in the active site in a similar configuration to the natural substrate. Optimizations were completed using M06-L/6-31G. M06-L was used since it is effective for intermolecular forces and interactions with metals [19]. A relaxed active site where the heavy atoms on the amino acid side chains and all protons were allowed to adjust their positions was used. Optimizations with implicit solvation were done via the PCM model using default parameters. The solvent in these cases was water. Interaction energies were also calculated from the solvent optimized structures. In all cases, counterpoise corrected interaction energies were calculated for the ligand/amino acid pairs and ligand $/ \mathrm{Zn}^{2+}$ using $\mathrm{M} 06-\mathrm{L} / 6-311+\mathrm{G}^{*}$. Calculations were performed using Gaussian09 [37].

\subsection{Synthesis of Acyclic Nucleoside Conjugate $\mathbf{1}$}

1-((2-Hydroxyethoxy)methyl)pyrimidine-2,4(1H,3H)-dione (5). To a flask containing uracil (1.51 $\mathrm{g}, 13.5 \mathrm{mmol})$ was added $\mathrm{CH}_{3} \mathrm{CN}(34 \mathrm{~mL}, 0.4 \mathrm{mmol} / \mathrm{mL})$ to form a suspension under Ar. At room temperature (r.t.), bis(TMS)acetamide $(9.25 \mathrm{~mL}, 37.8 \mathrm{mmol})$ was added slowly. After $1 \mathrm{~h}$ at r.t., 1,3-dioxolane (1.0 mL, $14.3 \mathrm{mmol}), \mathrm{KI}(2.22 \mathrm{~g}, 13.4 \mathrm{mmol})$ and TMSCl $(2.4 \mathrm{~mL}, 18.9 \mathrm{mmol})$ were added to the clear solution at r.t. After $16 \mathrm{~h}$, the yellow, cloudy reaction mixture was quenched with $\mathrm{MeOH}(25 \mathrm{~mL})$. The mixture turned white and was then neutralized with $\mathrm{NaHCO}_{3}$ (5.12 g, added in three portions, 2 min apart). The solid was removed by filtration and the filtrate was concentrated under reduced pressure. The crude product was purified by silica gel column chromatography (EtOAc: $\mathrm{MeOH}, 10-20 \% v / v$ ) The crystals formed in fractions were collected, while the liquid from the fractions was concentrated under reduced pressure. The non-crystalline solid was precipitated out with isopropanol, yielding 5 as an off-white solid $(835 \mathrm{mg}, 33 \%) . R_{\mathrm{f}}(4: 1 \mathrm{EtOAc}-\mathrm{MeOH})=0.44 .{ }^{1} \mathrm{H}-\mathrm{NMR}\left(\mathrm{DMSO}-d_{6}\right): \delta 3.46-3.50(\mathrm{~m}, 4 \mathrm{H}) 5.08(\mathrm{~s}, 2 \mathrm{H})$ $5.61(\mathrm{~d}, J=7.8 \mathrm{~Hz}, 1 \mathrm{H}) 7.70(\mathrm{~d}, J=7.8 \mathrm{~Hz}, 1 \mathrm{H}) 11.34(\mathrm{~s}, 1 \mathrm{H})$. The ${ }^{1} \mathrm{H}-\mathrm{NMR}$ data was similar to the literature values [38].

2-((2,4-Dioxo-3,4-dihydropyrimidin-1(2H)-yl)methoxy)ethyl 4-methylbenzenesulfonate (6). Compound 5 (230 mg, $1.24 \mathrm{mmol})$ was co-evaporated with pyridine $(3 \times 2 \mathrm{~mL})$ under Ar and was then redissolved in pyridine $(3.1 \mathrm{~mL}, 0.39 \mathrm{mmol} / \mathrm{mL})$ under $\mathrm{Ar}$ and $\mathrm{Ts}_{2} \mathrm{O}(640 \mathrm{mg}, 1.96 \mathrm{mmol})$ was added at $0{ }^{\circ} \mathrm{C}$. The reaction ran for $4.5 \mathrm{~h}$ at $30^{\circ} \mathrm{C}$. After $4.5 \mathrm{~h}$, the reaction mixture was diluted with $\mathrm{CH}_{2} \mathrm{Cl}_{2}$ and washed with $0.5 \mathrm{M} \mathrm{HCl}(4 \times 7 \mathrm{~mL})$, brine $(3 \times 3 \mathrm{~mL})$, and saturated $\mathrm{NaHCO}_{3}$ solution $(2 \times 7 \mathrm{~mL})$. The organic layer was collected, dried with $\mathrm{Na}_{2} \mathrm{SO}_{4}$, and concentrated under reduced pressure. The crude product 
was purified by silica gel column chromatography $\left(\mathrm{CH}_{2} \mathrm{Cl}_{2}: \mathrm{MeOH}, 10 \%\right)$. The reaction afforded the desired product $6(95 \mathrm{mg}, 23 \%)$ as a yellow solid. $R_{\mathrm{f}}(1: 4: 0.5 \mathrm{Hex}-\mathrm{EtOAc}-\mathrm{MeOH})=0.48 .{ }^{1} \mathrm{H}-\mathrm{NMR}$ $\left(\mathrm{CHCl}_{3}-d\right): \delta 2.41(\mathrm{~s}, 3 \mathrm{H}) 3.76(\mathrm{t}, J=4.4 \mathrm{~Hz}, 2 \mathrm{H}) 4.11(\mathrm{t}, J=4.4 \mathrm{~Hz}, 2 \mathrm{H}) 5.10(\mathrm{~s}, 2 \mathrm{H}) 5.72(\mathrm{~d}, J=7.0 \mathrm{~Hz}, 1 \mathrm{H})$ $7.25(\mathrm{~d}, J=7.8 \mathrm{~Hz}, 1 \mathrm{H}) 7.31(\mathrm{~d}, J=7.8 \mathrm{~Hz}, 2 \mathrm{H}) 7.73(\mathrm{~d}, J=7.0 \mathrm{~Hz}, 2 \mathrm{H}) 9.84(\mathrm{~s}, 1 \mathrm{H}) .{ }^{13} \mathrm{C}-\mathrm{NMR}\left(\mathrm{CDCl}_{3}\right)$ : $\delta 21.7,67.3,68.6,76.8,103.4,127.9,129.9,132.6,143.3,145.1,151.3,163.8$. The ${ }^{1} \mathrm{H}-\mathrm{NMR}$ data was similar to the literature values [38].

1-((2-Azidoethoxy)methyl)pyrimidine-2,4(1H,3H)-dione (7). Tosylate 6 (253 mg, $0.74 \mathrm{mmol})$ was dissolved in DMF $(1.8 \mathrm{~mL})$ under Ar. $\mathrm{NaN}_{3}(268 \mathrm{mg}, 4.12 \mathrm{mmol})$ was added to the solution. The reaction was stirred for $15 \mathrm{~h}$ at $45^{\circ} \mathrm{C}$. After $15 \mathrm{~h}$, the reaction was concentrated under reduced pressure. The crude product was purified by silica gel column chromatography $\left(\mathrm{CH}_{2} \mathrm{Cl}_{2}: \mathrm{MeOH}, 10 \%\right)$ to afford product 7 $(268 \mathrm{mg}, 70 \%)$ as a white solid. $R_{\mathrm{f}}\left(9: 1 \mathrm{CH}_{2} \mathrm{Cl}_{2}-\mathrm{MeOH}\right)=0.74 .{ }^{1} \mathrm{H}-\mathrm{NMR}\left(\mathrm{CDCl}_{3}\right): \delta 3.40-3.44(\mathrm{~m}, 5 \mathrm{H})$ $5.18(\mathrm{~m}, 2 \mathrm{H}) 5.75(\mathrm{dt}, J=7.9,1.6 \mathrm{~Hz}, 1 \mathrm{H}) 7.32(\mathrm{~d}, J=7.9 \mathrm{~Hz}, 1 \mathrm{H})$. The ${ }^{1} \mathrm{H}-\mathrm{NMR}$ data was similar to the literature values [38].

O-(But-3-yn-1-yl)-N-(tert-butoxycarbonyl)-L-serine (8). Boc-L-Ser-OH (246 mg, $1.20 \mathrm{mmol})$ and $\mathrm{K}_{2} \mathrm{CO}_{3}$ (348 mg, $2.52 \mathrm{mmol})$ were dissolved in anhydrous DMF (6.5 mL) under Ar. 4-Bromo-1-butyne (0.1 mL, $1.07 \mathrm{mmol}$ ) was added dropwise. The reaction mixture was heated to $45^{\circ} \mathrm{C}$ and stirred overnight. The reaction mixture was poured over ice cold $2 \mathrm{M} \mathrm{HCl}$, and the crude product was extracted with EtOAc $(2 \times 15 \mathrm{~mL})$ and the combined organic extract was washed with $2 \mathrm{M} \mathrm{HCl}(2 \times 15 \mathrm{~mL})$ and brine $(2 \times 15 \mathrm{~mL})$, concentrated and purified by silica gel column chromatography (Hex:EtOAc, 1:4, 1:3, $1: 2)$ to yield alkyne 8 as a pale yellow oil $(99 \mathrm{mg}, 38 \%) . R_{\mathrm{f}}(1: 4 \mathrm{Hex}-\mathrm{EtOAc})=0.75 .{ }^{1} \mathrm{H}-\mathrm{NMR}\left(\mathrm{CDCl}_{3}\right)$ : $\delta 5.47$ (br s, 1H), 4.34 (br s, 1H), 4.30-4.23 (m, 1H), 4.22-4.14 (m, 1H), 3.94 (dd, J = 3.5, 11.3 Hz, 1H), $3.83(\mathrm{dd}, J=3.5,11.3 \mathrm{~Hz}, 1 \mathrm{H}), 2.55-2.48(\mathrm{~m}, 2 \mathrm{H}), 1.97(\mathrm{t}, J=2.7 \mathrm{~Hz}, 1 \mathrm{H}), 1.39(\mathrm{~s}, 9 \mathrm{H}) .{ }^{13} \mathrm{C}-\mathrm{NMR}\left(\mathrm{CDCl}_{3}\right)$ : $\delta 18.7,28.2,55.7,62.9,70.2,79.7,155.7,170.7,173.0$.

N-(tert-Butoxycarbonyl)-O-(2-(1-(2-((2,4-dioxo-3,4-dihydropyrimidin-1(2H)-yl)methoxy)ethyl)-1H-1,2,3triazol-4-yl)ethyl)-L-serine (1a). In a $5 \mathrm{~mL}$ round bottom flask, azide 7 (103 $\mathrm{mg}, 0.49 \mathrm{mmol})$ was added to alkyne 8 (92 $\mathrm{mg}, 0.36 \mathrm{mmol})$ dissolved in $\mathrm{CH}_{3} \mathrm{CN}(0.7 \mathrm{~mL})$. The alkyne container was rinsed with $\mathrm{CH}_{3} \mathrm{CN}(0.5 \mathrm{~mL})$ and added to the reaction flask. To the flask was added DI water $(0.4 \mathrm{~mL}$, $1.74 \mathrm{mmol} / \mathrm{mL}$ ) and $\mathrm{Cu}$ powder $(9 \mathrm{mg}, 0.14 \mathrm{mmol})$. The reaction was ultra-sonicated for $10 \mathrm{~min}$ before being stirred at $35{ }^{\circ} \mathrm{C}$ overnight. At $21 \mathrm{~h}$, a second addition of $\mathrm{Cu}$ powder $(9 \mathrm{mg}, 0.14 \mathrm{mmol})$ was added. The reaction flask was ultra-sonicated for $10 \mathrm{~min}$ and stirred at $35^{\circ} \mathrm{C}$. At $24 \mathrm{~h}$, the reaction was concentrated under reduced pressure. The crude product was purified by silica gel column chromatography $\left(\mathrm{CH}_{2} \mathrm{Cl}_{2}: \mathrm{MeOH}, 5 \%\right)$ to afford the desired product 1 as a white solid $(112 \mathrm{mg}, 69 \%)$. $R_{\mathrm{f}}\left(9: 1 \mathrm{CH}_{2} \mathrm{Cl}_{2}-\mathrm{MeOH}\right)=0.38 .{ }^{1} \mathrm{H}-\mathrm{NMR}\left(\mathrm{CDCl}_{3}\right): \delta 1.43(\mathrm{~s}, 9 \mathrm{H}) 2.95-3.17(\mathrm{~m}, 2 \mathrm{H}) 3.79(\mathrm{~m}, 1 \mathrm{H})$ $4.01(\mathrm{t}, J=4.8 \mathrm{~Hz}, 2 \mathrm{H}) 4.15-4.27(\mathrm{~m}, 1 \mathrm{H}) 4.35(\mathrm{~d}, J=8.1 \mathrm{~Hz}, 1 \mathrm{H}) 4.52(\mathrm{t}, J=4.8 \mathrm{~Hz}, 2 \mathrm{H}) 4.56-4.66$ $(\mathrm{m}, 1 \mathrm{H}) 4.76(\mathrm{~s}, 1 \mathrm{H}) 5.11(\mathrm{~s}, 2 \mathrm{H}) 5.30(\mathrm{~s}, 2 \mathrm{H}) 5.69-5.78(\mathrm{~m}, 2 \mathrm{H}) 7.25(\mathrm{dd}, J=8.0,1.2 \mathrm{~Hz}, 1 \mathrm{H}) 7.57(\mathrm{~s}, 1 \mathrm{H})$ $9.81(\mathrm{~s}, 1 \mathrm{H}) .{ }^{13} \mathrm{C}-\mathrm{NMR}\left(\mathrm{CDCl}_{3}\right): \delta 25.0,28.3,49.9,53.5,56.1,62.8,64.1,67.7,79.9,103.2,123.02,143.69$, $144.19,151.43,155.79,163.92,171.15$.

\subsection{Synthesis of the Uridine-Amino Acid Conjugates 2-4}

1-((3aR,4R,6R,6aR)-6-(Hydroxymethyl)-2,2-dimethyltetrahydrofuro[3,4-d][1,3]dioxol-4-yl)pyrimidine-2,4 $(1 \mathrm{H}, 3 \mathrm{H})$-dione $(9)$. Uridine $(1.50 \mathrm{~g}, 6.14 \mathrm{mmol})$ was stirred in acetone $(75 \mathrm{~mL}, 0.08 \mathrm{mmol} / \mathrm{mL})$ and treated with $\mathrm{H}_{2} \mathrm{SO}_{4}(0.75 \mathrm{~mL})$ dropwise at r.t. and stirring at r.t. was continued. After $1.5 \mathrm{~h}$, the reaction was neutralized with $\mathrm{Et}_{3} \mathrm{~N}(2.25 \mathrm{~mL})$ and concentrated under reduced pressure. The crude mixture was purified by silica gel column chromatography $\left(\mathrm{CH}_{2} \mathrm{Cl}_{2}: \mathrm{MeOH}, 0-8 \%\right)$ to afford alcohol 9 (1.62 $\mathrm{g}$, $93 \%)$ as a white solid. $R_{\mathrm{f}}\left(9: 1 \mathrm{CH}_{2} \mathrm{Cl}_{2}-\mathrm{MeOH}\right)=0.33 .{ }^{1} \mathrm{H}-\mathrm{NMR}\left(\mathrm{CDCl}_{3}\right): \delta 1.36(\mathrm{~s}, 3 \mathrm{H}) 1.58(\mathrm{~s}, 3 \mathrm{H})$ 3.81-3.92 (m, 3H) $4.29(\mathrm{q}, J=3.4 \mathrm{~Hz}, 1 \mathrm{H}) 4.96(\mathrm{dd}, J=6.4,3.4 \mathrm{~Hz}, 1 \mathrm{H}) 5.04(\mathrm{dd}, J=6.4,2.9 \mathrm{~Hz}, 1 \mathrm{H})$ $5.61(\mathrm{~d}, J=2.9 \mathrm{~Hz}, 1 \mathrm{H}) 5.74(\mathrm{~d}, J=8.1 \mathrm{~Hz}, 1 \mathrm{H}) 7.41(\mathrm{~d}, J=8.0 \mathrm{~Hz}, 1 \mathrm{H}) 9.42(\mathrm{~s}, 1 \mathrm{H}) .{ }^{13} \mathrm{C}-\mathrm{NMR}\left(\mathrm{CDCl}_{3}\right)$ : $\delta 25.2,27.2,50.6,62.4,80.2,80.4,83.7,86.8,102.4,114.3,142.7,150.4$. The NMR data was similar to the literature values [25]. 
((3aR,4R,6R,6aR)-6-(2,4-Dioxo-3,4-dihydropyrimidin-1(2H)-yl)-2,2-dimethyltetrahydrofuro[3,4-d][1,3]dioxol-4-yl)methyl 4-methylbenzenesulfonate (10). Alcohol $9(0.90 \mathrm{~g}, 3.17 \mathrm{mmol})$ was dissolved in anhydrous $\mathrm{CH}_{2} \mathrm{Cl}_{2}(14 \mathrm{~mL})$ under Ar and pyridine $(2.7 \mathrm{~mL})$ was added. To the mixture was added $\mathrm{Ts}_{2} \mathrm{O}(1.71 \mathrm{~g}, 5.25 \mathrm{mmol})$. The light brown solution was heated under reflux for $2 \mathrm{~h}$. After $2 \mathrm{~h}$, the solution was diluted with $\mathrm{CHCl}_{3}(50 \mathrm{~mL})$ and washed with $0.5 \mathrm{M} \mathrm{HCl}(5 \times 22 \mathrm{~mL})$ and saturated $\mathrm{NaHCO}_{3}$ solution $(2 \times 22 \mathrm{~mL})$. The organic layer was dried over $\mathrm{Na}_{2} \mathrm{SO}_{4}$, filtered, and concentrated under reduced pressure. The crude product was purified by silica gel column chromatography $\left(\mathrm{CHCl}_{3}: \mathrm{MeOH}, 0-2 \%\right)$ to afford tosylate $10(1.06 \mathrm{~g}, 77 \%)$ as a red foam. $R_{\mathrm{f}}\left(\mathrm{CH}_{2} \mathrm{Cl}_{2}-\mathrm{MeOH}, 2 \%\right)=0.17$. ${ }^{1} \mathrm{H}-\mathrm{NMR}\left(\mathrm{CDCl}_{3}\right): \delta 1.31(\mathrm{~s}, 3 \mathrm{H}) 1.52(\mathrm{~s}, 3 \mathrm{H}) 2.41(\mathrm{~s}, 3 \mathrm{H}) 4.22-4.29(\mathrm{~m}, 2 \mathrm{H}) 4.29-4.35(\mathrm{~m}, 1 \mathrm{H}) 4.78$ $(\mathrm{dd}, J=6.4,3.8 \mathrm{~Hz}, 1 \mathrm{H}) 4.94(\mathrm{dd}, J=6.4,2.0 \mathrm{~Hz}, 1 \mathrm{H}) 5.63(\mathrm{~d}, J=2.0 \mathrm{~Hz}, 1 \mathrm{H}) 5.71(\mathrm{~d}, J=8.1 \mathrm{~Hz}, 1 \mathrm{H})$ $7.24(\mathrm{~d}, J=8.1 \mathrm{~Hz}, 1 \mathrm{H}) 7.31(\mathrm{~d}, J=8.0 \mathrm{~Hz}, 2 \mathrm{H}) 7.74(\mathrm{~d}, J=8.1 \mathrm{~Hz}, 2 \mathrm{H}) 9.89(\mathrm{~s}, 1 \mathrm{H})$. The NMR data was similar to the literature values [25].

1-((3aR,4R,6R,6aR)-6-(Azidomethyl)-2,2-dimethyltetrahydrofuro[3,4-d][1,3]dioxol-4-yl)pyrimidine-2,4$(1 \mathrm{H}, 3 \mathrm{H})$-dione (11). Tosylate 10 (153 mg, $0.35 \mathrm{mmol})$ was dissolved in DMF $(1 \mathrm{~mL})$ under Ar. $\mathrm{NaN}_{3}$ (110 $\mathrm{mg}, 1.70 \mathrm{mmol}$ ) was added to the solution. The reaction ran for 2 days (1st day at $\mathrm{rt}$, 2nd day at $45{ }^{\circ} \mathrm{C}$ ). The reaction mixture was concentrated under reduced pressure. The crude product was purified by silica gel column chromatography $\left(\mathrm{CH}_{2} \mathrm{Cl}_{2}: \mathrm{MeOH}, 0-20 \%\right)$ to afford azide 11 (103 mg, $96 \%)$ as a white solid. $R_{\mathrm{f}}(2: 3 \mathrm{Hex}-\mathrm{EtOAc})=0.36 .{ }^{1} \mathrm{H}-\mathrm{NMR}\left(\mathrm{CDCl}_{3}\right): \delta 1.36(\mathrm{~s}, 3 \mathrm{H}) 1.57(\mathrm{~s}, 3 \mathrm{H}) 3.63$ $(\mathrm{d}, J=5.2 \mathrm{~Hz}, 2 \mathrm{H}) 4.24(\mathrm{q}, J=5.0 \mathrm{~Hz}, 1 \mathrm{H}) 4.82(\mathrm{dd}, J=6.5,4.2 \mathrm{~Hz}, 1 \mathrm{H}) 5.01(\mathrm{dd}, J=6.5,2.1 \mathrm{~Hz}, 1 \mathrm{H}) 5.66$ $(\mathrm{d}, J=2.1 \mathrm{~Hz}, 1 \mathrm{H}) 5.77(\mathrm{~d}, J=8.0,1.4 \mathrm{~Hz}, 1 \mathrm{H}) 7.30(\mathrm{~d}, J=8.1 \mathrm{~Hz}, 1 \mathrm{H}) 9.50(\mathrm{~s}, 1 \mathrm{H})$. The NMR data was similar to the literature values [25].

$\mathrm{N}$-(tert-Butoxycarbonyl)-O-(2-(1-(((3aR,4R,6R,6aR)-6-(2,4-dioxo-3,4-dihydropyrimidin-1(2H)-yl)-2,2dimethyltetrahydrofuro[3,4-d][1,3]dioxol-4-yl)methyl)-1H-1,2,3-triazol-4-yl)ethyl)-L-serine (2a). Azide 11 ( $110 \mathrm{mg}, 0.43 \mathrm{mmol}$ ) was dissolved in $\mathrm{CH}_{3} \mathrm{CN}(1.5 \mathrm{~mL})$ and added to alkyne 8 ( $135 \mathrm{mg}, 0.44 \mathrm{mmol}$ ). DI $\mathrm{H}_{2} \mathrm{O}(0.5 \mathrm{~mL})$ was added to the reaction flask along with $\mathrm{Cu}$ powder $(5 \mathrm{mg}, 0.08 \mathrm{mmol})$. The reaction was sonicated for $10 \mathrm{~min}$ before stirring at $35^{\circ} \mathrm{C}$ overnight. The reaction was monitored by TLC ( $2: 3 \mathrm{Hex}: \mathrm{EtOAc})$. At $16 \mathrm{~h}$, the reaction was concentrated under reduced pressure, and the crude product (blue-green foam) was purified by silica gel column chromatography $\left(\mathrm{CH}_{2} \mathrm{Cl}_{2}-\mathrm{MeOH}, 2-5 \%\right)$ to afford product $2(207 \mathrm{mg}, 76 \%)$ as a white solid. $R_{\mathrm{f}}\left(9: 1 \mathrm{CH}_{2} \mathrm{Cl}_{2}-\mathrm{MeOH}\right)=0.60 .{ }^{1} \mathrm{H}-\mathrm{NMR}\left(\mathrm{CDCl}_{3}\right)$ : $\delta 10.04(\mathrm{br} \mathrm{s}, 1 \mathrm{H}), 7.46(\mathrm{~s}, 1 \mathrm{H}), 7.14(\mathrm{~d}, J=8.2 \mathrm{~Hz}, 1 \mathrm{H}), 5.68(\mathrm{~d}, J=8.2 \mathrm{~Hz}, 2 \mathrm{H}), 5.44(\mathrm{~d}, J=1.2 \mathrm{~Hz}, 1 \mathrm{H})$, $5.11-4.98(\mathrm{~m}, 1 \mathrm{H}), 4.86(\mathrm{dd}, J=4.3,6.3 \mathrm{~Hz}, 1 \mathrm{H}), 4.70-4.51(\mathrm{~m}, 3 \mathrm{H}), 4.46-4.37(\mathrm{~m}, 1 \mathrm{H}), 4.27(\mathrm{~d}, J=8.6 \mathrm{~Hz}$, $1 \mathrm{H}), 4.05(\mathrm{q}, J=7.0 \mathrm{~Hz}, 4 \mathrm{H}), 1.98(\mathrm{~s}, 3 \mathrm{H}), 1.47(\mathrm{~s}, 3 \mathrm{H}), 1.42-1.32(\mathrm{~m}, 9 \mathrm{H}), 1.27(\mathrm{~s}, 3 \mathrm{H}), 1.22-1.16(\mathrm{~m}, 3 \mathrm{H})$.

tert-Butyl ((2S)-1-oxo-1-((tetrahydro-2H-pyran-2-yl)oxy)amino)pent-4-yn-2-yl)carbamate (12). Boc-Lpropargylglycine $(584 \mathrm{mg}, 2.74 \mathrm{mmol}$ ) was measured out in a glove bag under an atmosphere of Ar. To the alkyne was added CDMT (484 mg, $2.76 \mathrm{mmol})$ and anhydrous THF $(19 \mathrm{~mL})$. At r.t., NMM $(0.35 \mathrm{~mL}, 3.18 \mathrm{mmol}, 1.16 \mathrm{eq})$ was added and the reaction mixture was stirred. After $1.5 \mathrm{~h}$, THP-O-NH 2 (373 mg, $3.18 \mathrm{mmol})$ was added. After $19.5 \mathrm{~h}$, the reaction mixture was filtered through Celite ( 2 inches). The Celite was rinsed with $\mathrm{CH}_{2} \mathrm{Cl}_{2}$. The resulting solution was concentrated and purified by silica gel column chromatography (Hex:EtOAc 1:4) to afford 12 (761 mg, 89\%). $R_{\mathrm{f}}(1: 4 \mathrm{Hex}-\mathrm{EtOAc})=0.73 .{ }^{1} \mathrm{H}-\mathrm{NMR}\left(\mathrm{CDCl}_{3}\right): \delta 1.38(\mathrm{~s}, 9 \mathrm{H}) 1.46-1.63(\mathrm{~m}, 4 \mathrm{H}) 1.68-1.83(\mathrm{~m}, 4 \mathrm{H})$ $2.60(\mathrm{~s}, 2 \mathrm{H}) 3.55(\mathrm{~m}, 1 \mathrm{H}) 3.91(\mathrm{~s}, 2 \mathrm{H}) 4.28(\mathrm{t}, J=7.0 \mathrm{~Hz}, 1 \mathrm{H}) 4.92(\mathrm{~d}, J=2.5 \mathrm{~Hz}, 1 \mathrm{H}) 5.54(\mathrm{~d}, J=7.7 \mathrm{~Hz}$, 1H) $9.96(\mathrm{~s}, 1 \mathrm{H}) .{ }^{13} \mathrm{C}-\mathrm{NMR}\left(\mathrm{CDCl}_{3}\right): \delta 167.6,102.3,80.3,79.1,77.1,71.5,62.3,54.8,50.8,24.9,22.6,20.9,18.5$.

(9H-Fluoren-9-yl)methyl (1-oxo-1-((tetrahydro-2H-pyran-2-yl)oxy)amino)pent-4-yn-2-yl)carbamate (13). Fmoc-L-propargylglycine $(511 \mathrm{mg}, 1.49 \mathrm{mmol})$ and THP-O-NH${ }_{2}(219 \mathrm{mg}, 1.64 \mathrm{mmol})$ were dissolved in anhydrous $\mathrm{CH}_{2} \mathrm{Cl}_{2}(2.5 \mathrm{~mL})$ under Ar gas. In a separate flask, DCC (340 mg, $\left.1.64 \mathrm{mmol}\right)$ was dissolved in anhydrous $\mathrm{CH}_{2} \mathrm{Cl}_{2}(3.5 \mathrm{~mL})$ under Ar gas and transferred dropwise to the solution containing Fmoc-L-propargylglycine and THP-O- $\mathrm{NH}_{2}$ at $0{ }^{\circ} \mathrm{C}$. The reaction mixture was then warmed to r.t. and ran for $19 \mathrm{~h}$. The crude mixture was filtered, concentrated under reduced pressure, and purified 
by silica gel column chromatography $\left(\mathrm{CH}_{2} \mathrm{Cl}_{2}: \mathrm{MeOH}, 5 \%\right)$ to afford $13(642 \mathrm{mg}, 96 \%)$ as a white solid. $R_{\mathrm{f}}\left(\mathrm{CH}_{2} \mathrm{Cl}_{2}-\mathrm{MeOH}, 5 \%\right)=0.66 .{ }^{1} \mathrm{H}-\mathrm{NMR}\left(\mathrm{CDCl}_{3}\right): \delta 9.99(\mathrm{br} \mathrm{s}, 1 \mathrm{H}), 7.73(\mathrm{~d}, J=7.4 \mathrm{~Hz}, 2 \mathrm{H})$, $7.56(\mathrm{~d}, J=7.0 \mathrm{~Hz}, 2 \mathrm{H}), 7.37(\mathrm{t}, J=7.5 \mathrm{~Hz}, 2 \mathrm{H}), 7.27(\mathrm{t}, J=7.5 \mathrm{~Hz}, 2 \mathrm{H}), 5.99(\mathrm{~d}, J=7.8 \mathrm{~Hz}, 1 \mathrm{H}), 5.27(\mathrm{~s}, 2 \mathrm{H})$, $4.95(\mathrm{br} \mathrm{s}, 1 \mathrm{H}), 4.54-4.26(\mathrm{~m}, 3 \mathrm{H}), 4.18(\mathrm{t}, J=7.0 \mathrm{~Hz}, 1 \mathrm{H}), 3.88(\mathrm{t}, J=10.0 \mathrm{~Hz}, 1 \mathrm{H}), 3.52(\mathrm{~d}, J=11.1 \mathrm{~Hz}$, $1 \mathrm{H}), 2.69$ (br s, 2H), 2.10-2.02 (m, 1H), 1.85-1.70 (m, 2H), 1.63-1.42 (m, 3H).

N-(1-Oxo-1-((tetrahydro-2H-pyran-2-yl)oxy)amino)pent-4-yn-2-yl)-[1,1'-biphenyl]-4-carboxamide (14). Compound $13(759 \mathrm{mg}, 1.75 \mathrm{mmol})$ was dissolved in anhydrous $\mathrm{CH}_{2} \mathrm{Cl}_{2}(3.5 \mathrm{~mL})$ under $\mathrm{Ar}$ and the solution was cooled to $0{ }^{\circ} \mathrm{C}$. Piperidine $(20 \%$ in DMF, $2 \mathrm{~mL})$ was added dropwise to the solution. After the reaction was complete, as determined by TLC, the reaction mixture was concentrated under pressure. Immediately following the deprotection reaction, the crude product, biphenyl-4-carboxylic acid $(285 \mathrm{mg}, 1.44 \mathrm{mmol}), \mathrm{EDC} \cdot \mathrm{HCl}(409 \mathrm{mg}, 2.13 \mathrm{mmol})$, and HOBt (303 mg, $1.98 \mathrm{mmol})$ were dissolved in anhydrous $\mathrm{CH}_{2} \mathrm{Cl}_{2}(15 \mathrm{~mL})$ under Ar gas at $0{ }^{\circ} \mathrm{C}$. Next, DIPEA $(1 \mathrm{~mL}, 5.74 \mathrm{mmol})$ was added to the reaction mixture at $0{ }^{\circ} \mathrm{C}$. The reaction ran for $1 \mathrm{~h}$ at $0{ }^{\circ} \mathrm{C}$ and then warmed to r.t. to run for $18 \mathrm{~h}$. After stopping the reaction, the reaction mixture was diluted with $\mathrm{CH}_{2} \mathrm{Cl}_{2}(15 \mathrm{~mL})$ and washed with $1.6 \mathrm{M}$ citric acid $\left(\mathrm{pH} \sim 3,30 \mathrm{~mL}\right.$ ), saturated $\mathrm{NaHCO}_{3}$ solution $(30 \mathrm{~mL})$, and brine (30 $\mathrm{mL}$ ). The organic layer was dried with $\mathrm{Na}_{2} \mathrm{SO}_{4}$, filtered, and concentrated under reduce pressure. The crude product was then purified via silica gel column chromatography $\left(\mathrm{CH}_{2} \mathrm{Cl}_{2}: \mathrm{MeOH}, 5 \%\right.$, Hex:EtOAc, 1:1) to produce $14(240 \mathrm{mg}, 35 \%)$ as a white solid. $R_{\mathrm{f}}(1: 1 \mathrm{Hex}-\mathrm{EtOAc})=0.44 .{ }^{1} \mathrm{H}-\mathrm{NMR}$ $\left(\mathrm{CDCl}_{3}\right): \delta 7.88(\mathrm{~m}, 2 \mathrm{H}), 7.67-7.51(\mathrm{~m}, 4 \mathrm{H}), 7.48-7.30(\mathrm{~m}, 4 \mathrm{H}), 5.09-4.98(\mathrm{~m}, 1 \mathrm{H}), 4.92(\mathrm{t}, J=6.7 \mathrm{~Hz}$, $1 \mathrm{H}), 4.16-4.05(\mathrm{~m}, 1 \mathrm{H}), 3.96(\mathrm{t}, J=9.0 \mathrm{~Hz}, 1 \mathrm{H}), 3.67-3.50(\mathrm{~m}, 1 \mathrm{H}), 2.96-2.77(\mathrm{~m}, 2 \mathrm{H}), 2.22-2.15(\mathrm{~m}, 1 \mathrm{H})$, $2.11(\mathrm{td}, J=2.6,5.4 \mathrm{~Hz}, 1 \mathrm{H}), 2.05-2.00(\mathrm{~m}, 2 \mathrm{H}), 1.95-1.71(\mathrm{~m}, 4 \mathrm{H}), 1.71-1.60(\mathrm{~m}, 2 \mathrm{H}), 1.60-1.46(\mathrm{~m}, 3 \mathrm{H})$, $1.27-1.20(\mathrm{~m}, 2 \mathrm{H}), 1.15-1.03(\mathrm{~m}, 1 \mathrm{H})$.

tert-Butyl ((2S)-3-(1-(((3aR,4R,6R,6aR)-6-(2,4-dioxo-3,4-dihydropyrimidin-1(2H)-yl)-2,2-dimethyltetrahydrofuro[3,4-d][1,3]dioxol-4-yl)methyl)-1H-1,2,3-triazol-4-yl)-1-oxo-1-((tetrahydro-2H-pyran-2-yl)oxy)amino)propan-2-yl)carbamate (15). Azide 11 (155 mg, $0.501 \mathrm{mmol})$ was dissolved in $\mathrm{CH}_{3} \mathrm{CN}(3.4 \mathrm{~mL})$ and added to alkyne $12(149 \mathrm{mg}, 0.477 \mathrm{mmol})$. DI water $(0.6 \mathrm{~mL})$ and $\mathrm{Cu}$ powder $(13 \mathrm{mg}, 0.21 \mathrm{mmol})$ were added. The reaction was sonicated for $10 \mathrm{~min}$ before stirring at $35^{\circ} \mathrm{C}$ overnight. At $21 \mathrm{~h}$, the reaction was concentrated under reduced pressure. The green crude product was purified by silica gel column chromatography $\left(\mathrm{CH}_{2} \mathrm{Cl}_{2}: \mathrm{MeOH} 6 \%\right)$ to afford the desired product $\mathbf{1 5}(225 \mathrm{mg}, 76 \%)$ as an off-white solid. $R_{\mathrm{f}}\left(\mathrm{CH}_{2} \mathrm{Cl}_{2}-\mathrm{MeOH}, 6 \%\right)=0.44 .{ }^{1} \mathrm{H}-\mathrm{NMR}\left(\mathrm{CDCl}_{3}\right): \delta 1.30(\mathrm{~s}, 3 \mathrm{H}) 1.37(\mathrm{~s}, 8 \mathrm{H}) 1.50(\mathrm{~s}, 6 \mathrm{H}) 1.72$ $(\mathrm{s}, 3 \mathrm{H}) 3.12(\mathrm{~s}, 1 \mathrm{H}) 3.54(\mathrm{~s}, 1 \mathrm{H}) 3.91(\mathrm{~m}, 1 \mathrm{H}) 4.41(\mathrm{~s}, 1 \mathrm{H}) 4.67(\mathrm{~s}, 1 \mathrm{H}) 4.86(\mathrm{~s}, 1 \mathrm{H}) 5.02(\mathrm{~s}, 1 \mathrm{H}) 5.54$ $(\mathrm{d}, J=10.2 \mathrm{~Hz}, 1 \mathrm{H}) 5.71(\mathrm{~s}, 1 \mathrm{H}) 5.82(\mathrm{~s}, 1 \mathrm{H}) 7.16(\mathrm{~s}, 1 \mathrm{H}) 7.43-7.66(\mathrm{~m}, 1 \mathrm{H})$ 10.24-10.47 (m, 1H).

N-(3-(1-(((3aR,4R,6R,6aR)-6-(2,4-Dioxo-3,4-dihydropyrimidin-1(2H)-yl)-2,2-dimethyltetrahydrofuro[3,4d][1,3]dioxol-4-yl)methyl)-1H-1,2,3-triazol-4-yl)-1-oxo-1-((tetrahydro-2H-pyran-2-yl)oxy)amino)propan-2-yl)[1,1'-biphenyl]-4-carboxamide (16). Azide 11 (179 mg, $0.58 \mathrm{mmol})$ was first dissolved in $\mathrm{CH}_{3} \mathrm{CN}(1.25 \mathrm{~mL})$, and the solution was transferred to a flask containing $14(240 \mathrm{mg}, 0.61 \mathrm{mmol})$. Upon dissolution of 14, $\mathrm{Cu}$ powder $(13 \mathrm{mg}, 0.20 \mathrm{mmol})$ and $\mathrm{DI}_{2} \mathrm{O}(1.0 \mathrm{~mL})$ were added to the reaction mixture. The reaction mixture was then subjected to sonication for $15 \mathrm{~min}$, and then stirred for $21 \mathrm{~h}$ at $35^{\circ} \mathrm{C}$. The crude reaction mixture was concentrated under reduced pressure and purified via silica gel column chromatography $\left(\mathrm{CH}_{2} \mathrm{Cl}_{2}: \mathrm{MeOH}, 5 \%\right)$ to yield $16(231 \mathrm{mg}, 57 \%)$ as a white solid. $R_{\mathrm{f}}\left(\mathrm{CH}_{2} \mathrm{Cl}_{2}-\mathrm{MeOH}\right.$, $5 \%)=0.32 .{ }^{1} \mathrm{H}-\mathrm{NMR}\left(\mathrm{CDCl}_{3}\right): \delta 7.87(\mathrm{~d}, J=8.2 \mathrm{~Hz}, 2 \mathrm{H}), 7.64-7.52(\mathrm{~m}, 5 \mathrm{H}), 7.46-7.39(\mathrm{~m}, 2 \mathrm{H})$, $7.36(\mathrm{~d}, J=7.4 \mathrm{~Hz}, 1 \mathrm{H}), 7.11(\mathrm{dd}, J=3.3,8.0 \mathrm{~Hz}, 1 \mathrm{H}), 5.70(\mathrm{~d}, J=7.8 \mathrm{~Hz}, 1 \mathrm{H}), 5.47(\mathrm{~d}, J=3.9 \mathrm{~Hz}, 1 \mathrm{H})$, $5.29(\mathrm{~s}, 3 \mathrm{H}), 5.01(\mathrm{t}, J=5.3 \mathrm{~Hz}, 1 \mathrm{H}), 4.98-4.89(\mathrm{~m}, 2 \mathrm{H}), 4.87-4.79(\mathrm{~m}, 1 \mathrm{H}), 4.66(\mathrm{~d}, J=5.1 \mathrm{~Hz}, 2 \mathrm{H})$, $4.45-4.36(\mathrm{~m}, 1 \mathrm{H}), 3.93(\mathrm{br} \mathrm{s}, 1 \mathrm{H}), 3.55(\mathrm{br} \mathrm{s}, 1 \mathrm{H}), 3.37(\mathrm{~d}, J=6.7 \mathrm{~Hz}, 1 \mathrm{H}), 3.24(\mathrm{br} \mathrm{s}, 1 \mathrm{H}), 1.74(\mathrm{br} \mathrm{s}, 2 \mathrm{H})$, $1.49(\mathrm{~s}, 3 \mathrm{H}), 1.26(\mathrm{~s}, 3 \mathrm{H})$.

(S)-2-Amino-3-(1-(( $(2 R, 3 S, 4 R, 5 R)-5-(2,4-d i o x o-3,4-d i h y d r o p y r i m i d i n-1(2 H)-y l)-3,4-d i h y d r o x y t e t r a h y d r o-$ furan-2-yl)methyl)-1H-1,2,3-triazol-4-yl)-N-hydroxypropanamide (3). Trifluoroacetic acid (3 $\mathrm{mL}, 90 \%$ in $\left.\mathrm{H}_{2} \mathrm{O}\right)$ was added to $15(187 \mathrm{mg}, 0.30 \mathrm{mmol})$ dissolved in $\mathrm{CH}_{2} \mathrm{Cl}_{2}(1 \mathrm{~mL})$ at $0{ }^{\circ} \mathrm{C}$. After $14.5 \mathrm{~h}$, 
the reaction was stopped and concentrated. The residue was rinsed with $\mathrm{CH}_{2} \mathrm{Cl}_{2}$ and concentrated followed by being transferred to a pear-flask in $\mathrm{MeOH}$. The residue was dissolved in $\mathrm{MeOH}$ and precipitated out with $\mathrm{Et}_{2} \mathrm{O}$ to yield product 3 as an off-white solid $(99 \mathrm{mg}, 65 \%) .{ }^{1} \mathrm{H}-\mathrm{NMR}\left(\mathrm{DMSO}-d_{6}\right)$ : $\delta 9.23(\mathrm{~s}, 1 \mathrm{H}), 7.80(\mathrm{~s}, 1 \mathrm{H}), 7.50(\mathrm{~d}, J=8.0 \mathrm{~Hz}, 1 \mathrm{H}), 5.67(\mathrm{~d}, J=5.2 \mathrm{~Hz}, 1 \mathrm{H}), 5.60(\mathrm{~d}, J=8.0 \mathrm{~Hz}, 1 \mathrm{H})$, $5.50(\mathrm{~d}, J=5.5 \mathrm{~Hz}, 1 \mathrm{H}), 5.35(\mathrm{~d}, J=5.5 \mathrm{~Hz}, 1 \mathrm{H}), 4.05$ (quin, $J=5.2 \mathrm{~Hz}, 2 \mathrm{H}), 3.90(\mathrm{q}, J=5.2 \mathrm{~Hz}, 1 \mathrm{H})$, $3.78(\mathrm{t}, J=7.0 \mathrm{~Hz}, 1 \mathrm{H}), 1.11-0.93(\mathrm{~m}, 4 \mathrm{H}) .{ }^{13} \mathrm{C}-\mathrm{NMR}\left(\mathrm{DMSO}-d_{6}\right): \delta 27.8,50.6,51.7,65.4,70.9,72.5,82.0$, 89.5, 102.6, 124.7, 140.9, 141.7, 151.1, 163.4. HRMS (ESI) $m / z$ calcd for $\left[\mathrm{C}_{14} \mathrm{H}_{20} \mathrm{~N}_{7} \mathrm{O}_{7}{ }^{+}\right] 398.1419$ found 398.1423.

N-(3-(1-(((2R,3S,4R,5R)-5-(2,4-Dioxo-3,4-dihydropyrimidin-1(2H)-yl)-3,4-dihydroxytetrahydrofuran-2yl)methyl)-1H-1,2,3-triazol-4-yl)-1-(hydroxyamino)-1-oxopropan-2-yl)-[1,1'-biphenyl]-4-carboxamide (4). For the deprotection reaction, $16(222 \mathrm{mg}, 0.32 \mathrm{mmol})$ was dissolved in $\mathrm{CH}_{2} \mathrm{Cl}_{2}$ at $0{ }^{\circ} \mathrm{C}$, to which DI $\mathrm{H}_{2} \mathrm{O}(0.40 \mathrm{~mL})$ and TFA $(1 \mathrm{~mL})$ were added dropwise. The reaction mixture warmed to r.t. and stirred for $20 \mathrm{~h}$. The crude reaction mixture was concentrated under reduced pressure and dissolved in 1:1 $\mathrm{CH}_{2} \mathrm{Cl}_{2}$ :MeOH (2 mL). The solution was transferred to a conical vial and concentrated under reduced pressure. Finally, the product was precipitated from a methanolic solution with $\mathrm{Et}_{2} \mathrm{O}$ to afford $4(128 \mathrm{mg}, 70 \%)$ as an off-white powder. ${ }^{1} \mathrm{H}-\mathrm{NMR}\left(\mathrm{DMSO}-d_{6}\right): \delta 11.32(\mathrm{br} \mathrm{s}, 1 \mathrm{H})$, $8.74(\mathrm{~d}, J=7.8 \mathrm{~Hz}, 1 \mathrm{H}), 7.92-7.80(\mathrm{~m}, 3 \mathrm{H}), 7.68(\mathrm{~d}, J=7.8 \mathrm{~Hz}, 2 \mathrm{H}), 7.72(\mathrm{~d}, J=8.2 \mathrm{~Hz}, 2 \mathrm{H}), 7.53-7.40$ $(\mathrm{m}, 3 \mathrm{H}), 7.40-7.32(\mathrm{~m}, 1 \mathrm{H}), 5.77-5.66(\mathrm{~m}, 1 \mathrm{H}), 5.59(\mathrm{~d}, J=7.8 \mathrm{~Hz}, 1 \mathrm{H}), 4.74-4.53(\mathrm{~m}, 3 \mathrm{H}), 4.07$ (br s, 1H), 4.04-3.97 (m, 1H), $3.90(\mathrm{t}, J=5.3 \mathrm{~Hz}, 1 \mathrm{H}), 3.29-3.07(\mathrm{~m}, 2 \mathrm{H}) .{ }^{13} \mathrm{C}-\mathrm{NMR}\left(\mathrm{DMSO}-d_{6}\right): \delta 27.4,51.5,53.1$, 65.4, 70.9, 72.6, 82.2, 89.2, 102.6, 124.7, 126.9, 127.3, 128.5, 129.5, 133.2, 139.6, 141.4, 143.4, 143.8, 151.1, 163.4, 164.6. HRMS (ESI) $m / z$ calcd for $\left[\mathrm{C}_{27} \mathrm{H}_{28} \mathrm{~N}_{7} \mathrm{O}_{8}{ }^{+}\right] 578.1994$ found 578.2012.

\section{Conclusions}

This is the first report of nucleoside analogue-amino acid conjugates linked via a 1,2,3-triazole group. Using computational methods, the electronic interaction energies of conjugates $\mathbf{1 b}, \mathbf{2 b}, \mathbf{3}$ and $\mathbf{4}$ were determined in the LpxC active site. In the more realistic solvated model, compound 3 showed the most favorable interaction energy. The modeling studies suggest that conjugates 3 and 4 have the most potential as inhibitors of LpxC. Despite less favorable interaction energies, compounds 1a and 2a were synthesized and characterized by ${ }^{1} \mathrm{H}-\mathrm{NMR}$. However, due to challenges in the synthesis of conjugates $\mathbf{1 a}$ and $\mathbf{2 a}$, particularly the alkylation of serine to afford the alkyne for the click reaction and the lower yields observed with the preparation of the azido acyclic nucleoside, these conjugates were not further pursued. The propargylglycine conjugates $\mathbf{3}$ and $\mathbf{4}$ were successfully synthesized using $\mathrm{CuAAC}$ to form a triazole linkage between the nucleoside and amino acid. The compounds were fully characterized by ${ }^{1} \mathrm{H}$ and ${ }^{13} \mathrm{C}-\mathrm{NMR}$ and HRMS, and the purity was determined by HPLC. Using COSY and NOESY experiments, the structure of 4 was further confirmed. The successful completion of the syntheses of these analogues allows for future comparative antibacterial studies to be performed.

Supplementary Materials: The following are available online, Figures S1 and S2: ${ }^{1} \mathrm{H}-{ }^{1} \mathrm{H}$ COSY and NOESY spectra, Table S1: Conditions for tosylation reaction.

Acknowledgments: The authors want to thank Karen Mosley for technical support with the NMR studies. This work was supported by Rhodes College and National Science Foundation grants CHE-1229354 and CHE-1626238.

Author Contributions: L.W.P. and M.C. conceived and designed the experiments; S.N.M., C.F.D., G.G.L. C.P.E., C.S.G. and L.W.P. performed the experiments; L.W.P., M.C., S.N.M., G.G.L. and C.P.E. analyzed the data; S.N.M., G.G.L. and L.W.P. wrote the manuscript.

Conflicts of Interest: The authors declare no conflict of interest.

\section{References}

1. Li, L.; Zhang, Z. Development and applications of the copper-catalyzed azide-alkyne cycloaddition (cuaac) as a bioorthogonal reaction. Molecules 2016, 21, 1393. [CrossRef] [PubMed] 
2. Bodnár, B.; Mernyák, E.; Wölfling, J.; Schneider, G.; Herman, B.E.; Szécsi, M.; Sinka, I.; Zupkó, I.; Kupihár, Z.; Kovács, L. Synthesis and biological evaluation of triazolyl $13 \alpha$-estrone-nucleoside bioconjugates. Molecules 2016, 21, 1212. [CrossRef] [PubMed]

3. Lima-Neto, R.G.; Cavalcante, N.N.M.; Srivastava, R.M.; Mendonca, F.J., Jr.; Wanderley, A.G.; Neves, R.P.; dos Anjos, J.V. Synthesis of 1,2,3-triazole derivatives and in vitro antifungal evaluation on candida strains. Molecules 2012, 17, 5882-5892. [CrossRef] [PubMed]

4. Maity, A.; Macaubas, C.; Mellins, E.; Astakhova, K. Synthesis of phospholipid-protein conjugates as new antigens for autoimmune antibodies. Molecules 2015, 20, 10253-10263. [CrossRef] [PubMed]

5. Chaudhary, P.M.; Chavan, S.R.; Shirazi, F.; Razdan, M.; Nimkar, P.; Maybhate, S.P.; Likhite, A.P.; Gonnade, R.; Hazara, B.G.; Deshpande, M.V.; et al. Exploration of click reaction for the synthesis of modified nucleosides as chitin synthase inhibitors. Bioorg. Med. Chem. 2009, 17, 2433-2440. [CrossRef] [PubMed]

6. Walvoort, M.T.C.; Lukose, V.; Imperiali, B. A modular approach to phosphoglycosyltransferase inhibitors inspired by nucleoside antibiotics. Chem. Eur. J. 2016, 22, 3856-3864. [CrossRef] [PubMed]

7. Szabó, J.; Jerkovics, N.; Schneider, G.; Wölfling, J.; Bózsity, N.; Minorics, R.; Zupkó, I.; Mernyák, E. Synthesis and in vitro antiproliferative evaluation of C-13 epimers of triazolyl-D-secoestrone alcohols: The first potent 13-D-secoestrone derivative. Molecules 2016, 21, 611. [CrossRef]

8. Oldham, E.D.; Nunes, L.M.; Varela-Ramirez, A.; Rankin, S.E.; Knutson, B.L.; Aguilera, R.J.; Lehmler, H.-J. Cytotoxic activity of triazole-containing alkyl $\beta$-D-glucopyranosides on a human T-cell leukemia cell line. Chem. Cent. J. 2015, 9, 3. [CrossRef] [PubMed]

9. Pastuch-Gawolek, G.; Plesniak, M.; Komor, R.; Byczek-Wyrostek, A.; Erfurt, K.; Szeja, W. Synthesis and preliminary biological assay of uridine glycoconjugate derivatives containing amide and/or 1,2,3-triazole linkers. Bioorg. Chem. 2017, 72, 80-88. [CrossRef] [PubMed]

10. Wen, Y.-N.; Zhang, Z.-F.; Liu, N.-N.; Xiang, Y.-H.; Zhang, Z.-Y.; Andrei, G.; Snoeck, R.; Schols, D.; Zhang, Q.-S.; $\mathrm{Wu}$, Q.-P. Synthesis and bioactivity of novel trisubstituted triazole nucleosides. Nucleosides Nucleotides Nucleic Acids 2016, 35, 147-160. [CrossRef] [PubMed]

11. Krajczyk, A.; Kulinska, K.; Kulinski, T.; Hurst, B.L.; Day, C.W.; Smee, D.F.; Ostrowski, T.; Januszczyk, P.; Zeidler, J. Antivirally active ribavirin analogues-4,5-disubstituted 1,2,3-triazole nucleosides: Biological evaluation against certain respiratory viruses and computational modelling. Antiviral Chem. Chemother. 2013, 23, 161-171. [CrossRef] [PubMed]

12. Ruddarraju, R.R.; Murugulla, A.C.; Kotla, R.; Chandra Babu Tirumalasetty, M.; Wudayagiri, R.; Donthabakthuni, S.; Maroju, R.; Baburao, K.; Parasa, L.S. Design, synthesis, anticancer, antimicrobial activities and molecular docking studies of theophylline containing acetylenes and theophylline containing 1,2,3-triazoles with variant nucleoside derivatives. Eur. J. Med. Chem. 2016, 123, 379-396. [CrossRef] [PubMed]

13. Alaoui, S.; Dufies, M.; Driowya, M.; Demange, L.; Bougrin, K.; Robert, G.; Auberger, P.; Pagès, G.; Benhida, R. Synthesis and anti-cancer activities of new sulfonamides 4-substituted-triazolyl nucleosides. Bioorg. Med. Chem. Lett. 2017, 27, 1989-1992. [CrossRef] [PubMed]

14. Fer, M.J.; Bouhss, A.; Patrao, M.; Le Corre, L.; Pietrancosta, N.; Amoroso, A.; Joris, B.; Mengin-Lecreulx, D.; Calvet-Vitale, S.; Gravier-Pelletier, C. 5'-methylene-triazole-substituted-aminoribosyl uridines as mray inhibitors: Synthesis, biological evaluation and molecular modeling. Org. Biomol. Chem. 2015, 13, 7193-7222. [CrossRef] [PubMed]

15. Barb, A.W.; Jiang, L.; Raetz, C.R.H.; Zhou, P. Structure of the deacetylase lpxc bound to the antibiotic chir-090: Time-dependent inhibition and specificity in ligand binding. Proc. Natl. Acad. Sci. USA 2007, 104, 18433-18438. [CrossRef] [PubMed]

16. Levy, S.B. Antibiotic resistance-The problem intensifies. Adv. Drug Deliv. Rev. 2005, 57, 1446-1450. [CrossRef] [PubMed]

17. Mansoor, U.F.; Reddy, P.A. Hydantoin Derivatives Useful as Antibacterial Agents. U.S. Patent 7,998,961, 29 August 2007.

18. Barb, A.W.; Zhou, P. Mechanism and inhibition of lpxc: An essential zinc-dependent deacetylase of bacterial lipid a synthesis. Curr. Pharm. Biotechnol. 2008, 9, 9-15. [PubMed]

19. Zhao, Y.; Truhlar, D.G. A new local density functional for main-group thermochemistry, transition metal bonding, thermochemical kinetics, and noncovalent interactions. J. Chem. Phys. 2006, 125, 194101. [CrossRef] [PubMed]

20. Rassolov, V.A.; Pople, J.A.; Ratner, M.A.; Windus, T.L. 6-31G* basis set for atoms K through Zn. J. Chem. Phys. 1998, 109, 1223-1229. [CrossRef] 
21. Gennadios, H.A.; Christianson, D.W. Binding of uridine $5^{\prime}$-diphosphate in the "basic patch" of the zinc deacetylase lpxc and implications for substrate binding. Biochemistry 2006, 45, 15216-15223. [CrossRef] [PubMed]

22. Cossi, M.; Barone, V.; Cammi, R.; Tomasi, J. Ab initio study of solvated molecules: A new implementation of the polarizable continuum model. Chem. Phys. Lett. 1996, 255, 327-335. [CrossRef]

23. Boys, S.F.; Bernardi, F. The calculation of small molecular interactions by the differences of separate total energies. Some procedures with reduced errors. Mol. Phys. 1970, 19, 553-566. [CrossRef]

24. Sauer, R.; El-Tayeb, A.; Kaulich, M.; Mueller, C.E. Synthesis of uracil nucleotide analogs with a modified, acyclic ribose moiety as P2Y2 receptor antagonists. Bioorg. Med. Chem. 2009, 17, 5071-5079. [CrossRef] [PubMed]

25. Winans, K.A.; Bertozzi, C.R. An inhibitor of the human udp-glcnac 4-epimerase identified from a uridine-based library. A strategy to inhibit O-linked glycosylation. Chem. Biol. 2002, 9, 113-129. [CrossRef]

26. Zhang, X.; Shen, X.; Yan, H.; Chen, H. Synthesis, spectroscopic characterization, axial base coordination equilibrium and photolytic kinetics studies of a new coenzyme $B_{12}$ analogue- $3^{\prime}$-deoxy-2', $3^{\prime}$-anhydrothymidylcobalamin. Dalton Trans. 2007, 2336-2342. [CrossRef] [PubMed]

27. Lin, T.S.; Prusoff, W.H. A novel synthesis and biological activity of several 5-halo-5'-amino analogues of deoxyribopyrimidine nucleosides. J. Med. Chem. 1978, 21, 106-109. [CrossRef] [PubMed]

28. Kawaguchi, M.; Okabe, T.; Okudaira, S.; Nishimasu, H.; Ishitani, R.; Kojima, H.; Nureki, O.; Aoki, J.; Nagano, T. Screening and X-ray crystal structure-based optimization of autotaxin (enpp2) inhibitors, using a newly developed fluorescence probe. ACS Chem. Biol. 2013, 8, 1713-1721. [CrossRef] [PubMed]

29. Pontikis, R.; Benhida, R.; Aubertin, A.-M.; Grierson, D.S.; Monneret, C. Synthesis and anti-hiv activity of novel N-1 side chain-modified analogs of 1-[(2-hydroxyethoxy)methyl]-6-(phenylthio)thymine (HEPT). J. Med. Chem. 1997, 40, 1845-1854. [CrossRef] [PubMed]

30. Wagner, H.; Brinks, M.K.; Hirtz, M.; Schaefer, A.; Chi, L.-F.; Studer, A. Chemical surface modification of self-assembled monolayers by radical nitroxide exchange reactions. Chem. Eur. J. 2011, 17, 9107-9112. [CrossRef] [PubMed]

31. Margalith, I.; Suter, C.; Ballmer, B.; Schwarz, P.; Tiberi, C.; Sonati, T.; Falsig, J.; Nystroem, S.; Hammarstroem, P.; Aslund, A.; et al. Polythiophenes inhibit prion propagation by stabilizing prion protein (prp) aggregates. J. Biol. Chem. 2012, 287, 18872-18887. [CrossRef] [PubMed]

32. Jawalekar, A.M.; Meeuwenoord, N.; Cremers, J.G.O.; Overkleeft, H.S.; van der Marel, G.A.; Rutjes, F.P.J.T.; van Delft, F.L. Conjugation of nucleosides and oligonucleotides by [3+2] cycloaddition. J. Org. Chem. 2008, 73, 287-290. [CrossRef] [PubMed]

33. Bello, A.M.; Poduch, E.; Fujihashi, M.; Amani, M.; Li, Y.; Crandall, I.; Hui, R.; Lee, P.I.; Kain, K.C.; Pai, E.F.; et al. A potent, covalent inhibitor of orotidine $5^{\prime}$-monophosphate decarboxylase with antimalarial activity. J. Med. Chem. 2007, 50, 915-921. [CrossRef] [PubMed]

34. Wang, R.; Steensma, D.H.; Takaoka, Y.; Yun, J.W.; Kajimoto, T.; Wong, C.-H. A search for pyrophosphate mimics for the development of substrates and inhibitors of glycosyltransferases. Bioorg. Med. Chem. 1997, 5, 661-672. [CrossRef]

35. Jackman, J.E.; Fierke, C.A.; Tumey, L.N.; Pirrung, M.; Uchiyama, T.; Tahir, S.H.; Hindsgaul, O.; Raetz, C.R.H. Antibacterial agents that target lipid a biosynthesis in gram-negative bacteria: Inhibition of diverse udp-3-O-(R-3-hydroxymyristoyl)- $N$-acetylglucosamine deacetylases by substrate analogs containing zinc binding motifs. J. Biol. Chem. 2000, 275, 11002-11009. [CrossRef] [PubMed]

36. Liang, X.; Lee, C.-J.; Chen, X.; Chung, H.S.; Zeng, D.; Raetz, C.R.H.; Li, Y.; Zhou, P.; Toone, E.J. Syntheses, structures and antibiotic activities of lpxc inhibitors based on the diacetylene scaffold. Biorg. Med. Chem. 2011, 19, 852-860. [CrossRef] [PubMed]

37. Gaussian 09, Revision C.01; Gaussian Inc.: Wallingford, CT, USA, 2009.

38. Abrams, H.M.; Ho, L.; Chu, S.H. Synthesis of pyrimidine acyclonucleosides. J. Heterocycl. Chem. 1981, 18, 947-951. [CrossRef]

(C) 2017 by the authors. Licensee MDPI, Basel, Switzerland. This article is an open access article distributed under the terms and conditions of the Creative Commons Attribution (CC BY) license (http:/ / creativecommons.org/licenses/by/4.0/). 